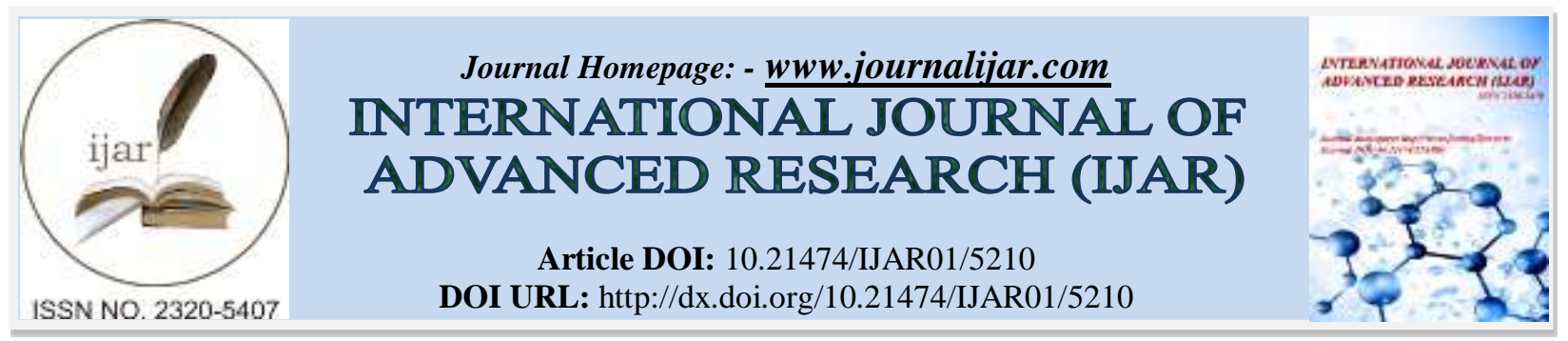

RESEARCH ARTICLE

\title{
RETURN ON EQUITY ANALYSIS USING DUPONT MODEL.
}

Tushar Shani ${ }^{1}$, Tinish Gupta ${ }^{2}$, Nitish ${ }^{3}$ and Ankit Parashar ${ }^{4}$

1. UG students, Mechanical Engineering Dept., Indian Institute of Technology, Delhi, India.

2. UG students, Civil Engineering Dept., Indian Institute of Technology, Delhi, India.

\section{Manuscript Info}

Manuscript History

Received: 18 June 2017

Final Accepted: 20 July 2017

Published: August 2017

Key words:-

DuPont model, 2-part, 3-part, 5-part, RoE, RoA, EBIT, EBT

\begin{abstract}
This paper puts forward the DuPont model for three firms in the beverages industry namely - Pepsi, Coke \& Lehar. This model is a useful tool for comprehensive Final analysis of Return of Equity (RoE), an important indicator of firm's ability to turn shareholder's investment into profitable returns. In the paper, it is shown that Return of Equity (RoE) should not be the sole criteria to judge a firm's financial wellbeing, therefore a gamut of intermediary indicators like EBIT, Asset turnover ratio etc. are enumerated for the firms for performance analysis through DuPont model. On the basis of the model, the relative performances of the three firms are put as conclusion profit margin, asset turnover, and equity multiplier.
\end{abstract}

Copy Right, IJAR, 2017, All rights reserved.

\section{Introduction:-}

Return of Equity (RoE) is one of the strongest indicators measuring the financial well-being of a firm. This represents the return on that portion of the company belonging to equity \& is a clear indicator of the management's ability to turn share-holders investment into profitable returns. But at the same time, Return of Equity (RoE) a tricky indicator that can be manipulated to higher values without real increase in the performance of the firm. One such way of doing so is by increasing debt as this reduces the relative contribution of equity, which serves as a denominator in Return of Equity (RoE) calculation. At the cost of higher Return of Equity (RoE) by debts, the firm loses stability in down markets.

Return of Equity (RoE) can be broken down into following key performance parameters, which highlights the financial strategy adopted by the company:

$$
\text { RoE }=(\text { Net Profit Margin }) \times(\text { Total Asset Turnover }) \times(\text { Equity multiplier })
$$

- Net Profit Margin: This parameter represents the percentage of revenue left after all the expenses are deducted from sales. The measurement reveals the amount of profit that a business can extract from its total sales

$$
\text { Net Profit Margin }=\frac{\text { Net profit }}{\text { Total Sales Revenue }}
$$

- Total Asset Turnover: This parameter represents the efficiency of a company's use of its asset in generating sales revenue or sales income to the company.

$$
\text { Asset Turnover }=\frac{\text { Net Sales Revenue }}{\text { Average Total Assets }}
$$


Companies with low profit margins tend to have high asset turnover, while those with high profit margins have low asset turnover. Companies in the retail industry tend to have a very high turnover ratio due mainly to cutthroat and competitive pricing.

- Equity Multiplier: This parameter is measure of financial leverage an individual owes to the firm. It can be understood as the ratio of average total assets and shareholder's equity.

$$
\text { Equity Multiplier }=\frac{\text { Average Total Assets }}{\text { Shareholder's Equity }}
$$

High amount of leverage leads to more instability in the profit returns of the firm. Therefore, it makes the investment risky. In a high returning firm, the risk is generally high, thus it necessary to find optimal return and risk combination. Equity multiplier can be a useful tool for the purpose.

\section{Brief History:-}

The DuPont model was first used by the DuPont Corporation in 1920s and hence it was named after the company. The DuPont explosives salesman Donaldson Brown was the person who invented this method in 1912. He first utilized as a part of an internal analysis report for the company. Later, this method was widely used to model the performance of most company worldwide, finding its application in high profit margin, turnover ratio or leverage industries. This analysis enables the analyst to understand the source of superior (or inferior) return by comparison with companies in similar industries (or between industries).

\section{DuPont Model:-}

This model fundamentally breaks down the Return of Equity (RoE) into multiple parts and analyzes those individual parts to make a clearer picture of the firm's financial ability. The DuPont analysis involves the decomposition of expression for the Return of Equity (RoE) into 2 components, 3 components or 5 components. The analysis is correspondingly called 2-part DuPont analysis, 3-part DuPont analysis or 5-part DuPont analysis.

\section{- 2-Part DuPont Analysis:}

In this method of analysis the Return of Equity (RoE) is divided into two parts namely- the Return of Assets (RoA) and Equity multiplier (leverage).

$$
\text { RoE }=\text { RoA } \times \text { Equity multiplier }
$$

Return of Assets (RoA) ratio is a parameter developed by the DuPont Corporation to develop this model. It is the ratio of the Net profit from sales and Average Total Asset value. It combines the effect of the Net profit margin and Asset turnover.

$$
R o A=\frac{\text { Net Profit from sales }}{\text { Average Total Assets }}
$$

According to this model, for two companies with same Return of Equity (RoE), the firm having greater contribution of Return of Asset (RoA) as compared to Equity multiplier (Leverages), has superior returns.

\section{- 3-Part DuPont Analysis:}

The 2-part DuPont analysis method is unable to evaluate the firms at a more detailed way i.e. it is devoid of parameters like Net profit margin and Asset turnover of the company, which give further insight into the strategy adopted by the company to achieve the profits.

This method of analysis divides the Return of Equity (RoE) into three parts namely- Net profit margin, Total Asset turnover and Equity multiplier (leverage).

$$
\text { RoE }=\text { Net profit margin } \times \text { Total Asset Turnover } \times \text { Equity multiplier }
$$

This method is a more detailed version of the 2-part analysis, wherein the Return of Assets (RoA) is further broken into Net profit margin and Total asset turnover. Therefore, allowing an analyst to evaluate firm with more detail. If two companies have same level of Return of Asset (RoA), but one has high Asset turnover, i.e. a higher market share. Whereas, the other company has a higher net profit margin, i.e. higher brand value. A good analyst should be able to identify such strengths of companies and recommend a suitable course of action. 


\section{- 5-Part DuPont Analysis:}

In the 3-Part DuPont analysis, the Net profit is considered to be the profit generated after deduction of interest and taxes applicable to the sales. This method evaluates the net profit margin at three different stages namely- EBIT (Earnings before interest and taxes), Pretax Earnings and finally Net Earnings. These stages are inculcated in the form of Interest burden, Tax burden and EBIT margin. So, the Net profit margin can be written as:

$$
\text { Net profit margin }=(\text { Interest burden }) \times(\text { Tax burden }) \times(\text { EBIT margin })
$$

Now combine this expression with that of Return of Equity (RoE), we get following formula for the Return of Equity (RoE):

\section{RoE $=$ Tax burden $\times$ Interest burden $\times$ EBIT margin $\times$ Total Asset turnover $\times$ Equity multiplier}

This is the basic expression for the 5-part DuPont analysis. Generally, the tax burden is not a variable factor when comparing firms of same industry, thus does not play a major role. But, the Interest burden should be as close as possible to 1.00 i.e. the pretax earnings and EBIT should be same or the firm has no debt or financial leverage. If two companies having same Return on Equity (RoE), Return on Asset (RoA) and Net profit margin, then the firm having Interest burden closer to 1.00 has superior returns as compared to the one with lower interest burden. This gives another level of detail for an analyst to take into consideration and recommend a course of action.

\section{Case Study:-}

This section presents the DuPont analysis done for three firms in the beverages industry namely - Pepsi, Coke \& Lehar. Following is data collected for these industries to carry out DuPont analysis:

\begin{tabular}{|c|c|c|c|c|}
\hline Coke & 2015 & 2014 & 2013 & 2012 \\
\hline RoE & $27.5 \%$ & $42.3 \%$ & $30.1 \%$ & \\
\hline NI & $\square 8,572$ & $\square 11,809$ & $\square 6,824$ & \\
\hline TA & $\square 79,974$ & $\square 72,921$ & $\square 48,671$ & $\square 40,519$ \\
\hline Av TA & $\square 76,447$ & $\square 60,796$ & $\square 44,595$ & \\
\hline SEq & $\square 31,365$ & $\square 31,003$ & $\square 24,799$ & $\square 20,472$ \\
\hline Av SEq & $\square 31,184$ & $\square 27,901$ & $\square 22,635$ & \\
\hline $\operatorname{Rev}$ & $\square 46,542$ & $\square 35,119$ & $\square 30,990$ & \\
\hline EBT & $\square 11,439$ & $\square 14,243$ & $\square 8,946$ & \\
\hline EBIT & $\square 10,732$ & $\square 13,741$ & $\square 8,231$ & \\
\hline Pepsi & 2015 & 2014 & 2013 & 2012 \\
\hline RoE & $30.9 \%$ & $32.8 \%$ & $41.1 \%$ & \\
\hline NI & $\square 6,443$ & $\square 6,230$ & $\square 5,946$ & \\
\hline TA & $\square 72,882$ & $\square 68,153$ & $\square 39,848$ & $\square 35,994$ \\
\hline Av TA & $\square 70,517$ & $\square 54,000$ & $\square 37,921$ & \\
\hline SEq & $\square 20,588$ & $\square 21,164$ & $\square 16,804$ & $\square 12,106$ \\
\hline Av SEq & $\square 20,876$ & $\square 18,984$ & $\square 14,455$ & \\
\hline $\operatorname{Rev}$ & $\square 66,504$ & $\square 57,838$ & $\square 43,232$ & \\
\hline EBT & $\square 8,834$ & $\square 8,232$ & $\square 8,079$ & \\
\hline EBIT & $\square 9,633$ & $\square 8,332$ & $\square 8,044$ & \\
\hline Lehar & 2015 & 2014 & 2013 & 2012 \\
\hline RoE & $7 \%$ & $12 \%$ & $26.5 \%$ & \\
\hline NI & $\square 38$ & $\square 55$ & $\square 82$ & \\
\hline TA & $\square 1,509$ & $\square 1,529$ & $\square 874$ & $\square 873$ \\
\hline Av TA & $\square 1,519$ & $\square 1,201$ & $\square 873$ & \\
\hline SEq & $\square 556$ & $\square 522$ & $\square 386$ & $\square 229$ \\
\hline Av SEq & $\square 539$ & $\square 454$ & $\square 308$ & \\
\hline Rev & $\square 2,335$ & $\square 1,803$ & $\square 1,597$ & \\
\hline EBT & $\square 41$ & $\square 78$ & $\square 63$ & \\
\hline EBIT & $\square 101$ & $\square 99$ & $\square 97$ & \\
\hline
\end{tabular}

Here:

$\mathrm{NI}=$ Net Income 
TA $=$ Total Assets

Av = Average

$\mathrm{SEq}=$ Shareholders Equity

$\mathrm{EBT}=$ Earnings Before Taxes

Following table shows the calculated values of 5 parameters to be used for carrying out DuPont analysis:

\begin{tabular}{|l|l|l|l|}
\hline Coke & $\mathbf{2 0 1 5}$ & $\mathbf{2 0 1 4}$ & $\mathbf{2 0 1 3}$ \\
\hline RoE & 0.2749 & 0.4232 & 0.3015 \\
\hline Tax Burden & 0.7494 & 0.8291 & 0.7628 \\
\hline Interest Burden & 1.0659 & 1.0365 & 1.0869 \\
\hline EBIT Margin & 0.2306 & 0.3913 & 0.2656 \\
\hline Asset Turnover & 0.6088 & 0.5777 & 0.6949 \\
\hline Leverage & 2.4515 & 2.1790 & 1.9701 \\
\hline Pepsi & $\mathbf{2 0 1 5}$ & $\mathbf{2 0 1 4}$ & $\mathbf{2 0 1 3}$ \\
\hline RoE & 0.3086 & 0.3282 & 0.4113 \\
\hline Tax Burden & 0.7293 & 0.7568 & 0.7360 \\
\hline Interest Burden & 0.9171 & 0.9880 & 1.0044 \\
\hline EBIT Margin & 0.1448 & 0.1441 & 0.1861 \\
\hline Asset Turnover & 0.9431 & 1.0711 & 1.1401 \\
\hline Leverage & 3.3779 & 2.8445 & 2.6234 \\
\hline Lehar & $\mathbf{2 0 1 5}$ & $\mathbf{2 0 1 4}$ & $\mathbf{2 0 1 3}$ \\
\hline RoE & 0.0698 & 0.1205 & 0.2650 \\
\hline Tax Burden & 0.9284 & 0.6977 & 1.2875 \\
\hline Interest Burden & 0.7919 & 0.6499 \\
\hline EBIT Margin & 0.4022 & 0.0549 & 0.0610 \\
\hline Asset Turnover & 0.0431 & 1.5009 & 1.8280 \\
\hline Leverage & 1.5369 & 2.6459 & 2.8396 \\
\hline The & 2.8183 & (n) & \\
\hline
\end{tabular}

The four major parameters that will be considered for analysis will be RoE, EBIT Margin, Asset Turnover and Leverage.

\section{Return of Equity:-}

RoE average for the S\&P 500 for the past 3 decades has been around 12\%. Keeping this in mind, Coke is doing fairly well with RoE values well above the market average Pepsi shows trends similar to Coke but as it varies over a lower range and has a minimum higher than Coke, it is considered slightly better. Lehar has a declining RoE which eventually falls below the market average. So, it is ruled out at this point.

\section{EBIT Margin:-}

Coke is observed to have the highest profit margin owing to its leadership in global market enabling them to charge a premium. Pepsi's margins are high, though lower than Coke, and consistent. Lehar shows a weak trend again implying that it is a low cost producer. Advertisements are unaffordable for them and this product has been reduced to the status of a commodity.

\section{Asset Turnover:-}

Coke is the bottom line player here and it is surprising as being a huge producer it should be able to encase the economies of scale. The high profit margin compensates for this low. Pepsi has a consistent and high asset turnover. Lehar leads the market in this parameter owing to its low cost of production. Still the RoE trends are not compensated by this fact.

\section{Leverage:-}

Coke has the least leverage making it a stable company even if the beverage industry suffers a shock. Effective management is the reason for low leverage and high RoE. Pepsi has highest leverage signifying its strategy of making the most of a market bull run but at the risk of a lot of loss in down market. Increasing leverage is a matter of concern. Lehar has a sizeable leverage if the profit margins are considered into account. It is trying hard to maintain consistent leverages. 


\begin{abstract}
Analysis:-
By observing the companies on four parameters, it can be concluded that: Coke is taking advantage of its brand name to sell products at a premium which leads to lower asset turnovers but higher profit margins. Pepsi is playing a balanced game maintaining a decent assist turnover and profit margin. It has the brand name to add a premium but it has efficiently balanced turnovers with it. Lehar is a low cost producer selling product as a commodity. It focuses on high assist turnover on lower margins but the market share owned by Lehar is not favorable for this kind of strategy to succeed.
\end{abstract}

In a nutshell, Coke is a long term player with faith in its brand name; Pepsi is an opportunity-seeker and Lehar is just ruled out of option.

\title{
Conclusion:-
}

It is clear from the example that DuPont Analysis is a powerful tool to break down a firm's RoE into parts for getting a clear picture of the strategies adopted by the firm. It is a powerful tool for the management as well to compare its performance with the market and figure out possibilities of improvement. Therefore, this tool can be extensively utilized by the analysts to make a comprehensive recommendation for improving the financial wellbeing of a firm. The ultimate motive is to achieve an acceptable RoE. But the investor must be aware of the factors contributing to it and thus should be able to decipher risks and understand benefits from investing in a firm.

\section{References:-}

1. Phillips, Matt (9 December 2015). "The DuPont invention that changed how things work in the corporate world". Quartz (publication). Retrieved 9 December 2015

2. Groppelli, Angelico A.; Ehsan Nikbakht (2000). Finance, 4th ed. Barron's Educational Series, Inc. pp. 444445. ISBN 0-7641-1275-9

3. Groppelli, Angelico A.; Ehsan Nikbakht (2000). Finance, 4th ed. Barron's Educational Series, Inc. p. 444. ISBN 0-7641-1275-9

4. Bodie, Zane; Alex Kane; Alan J. Marcus (2004). Essentials of Investments, 5th ed. McGraw-Hill Irwin. pp. 458-459. ISBN 0-07-251077-3

5. Bodie, Zane; Alex Kane; Alan J. Marcus (2004). Essentials of Investments, 5th ed. McGraw-Hill Irwin. p. 459. ISBN 0-07-251077-3

6. Brigham, Eugene F., Fundamentals of Financial Management (1995)

7. Weston, J. Fred and Eugene F. Brigham, Managerial Finance (1969)

8. "Profitability Indicator Ratios: Return On Equity", Richard Loth Investopedia

9. Woolridge, J. Randall and Gray, Gary; Applied Principles of Finance (2006)

10. Bodie, Kane, Markus, "Investments" 